\title{
Influence of Supportive and Directive Leadership Styles on Employee Job Satisfaction in Commercial Banks in Kenya
}

\author{
Davidson Mghanga Mwaisaka \\ Research Scholar, Chandaria School of Business \\ United States International University-Africa \\ Email: mghangawamwaisaka@yahoo.com \\ Prof. George K'Aol \\ Chandaria School of Business \\ United States International University-Africa \\ P.O. Box 14634-0800, Nairobi, Kenya \\ Dr. Caren Ouma \\ Chandaria School of Business \\ United States International University-Africa \\ P.O. Box 14634-0800, Nairobi, Kenya
}

\begin{abstract}
The purpose of the study was to investigate the influence of supportive and directive leadership style on employee job satisfaction in commercial banks in Kenya. The study adopted positivism research philosophy to guide the study and limited itself to descriptive correlational research design to analyze and provide responses to the research questions. The research design was preferred because it allows description and comparison of characteristics of populations based on data collected from samples through questionnaires. The target population of the study was 15,030 employees in all the 43 commercial banks licensed to operate in Kenya as of June 2018. Using stratified sampling technique, the study drew a sample size of 386 employees reporting to middle level managers. Data was collected by means of a questionnaire and analyzed using descriptive and inferential statistics, which included factor analysis, correlational analysis, chi-square, one-way analysis of variance (ANOVA), and regression analysis using Statistical Package for Social Sciences (SPSS) version 20 and Windows' Microsoft excel programs.

From the findings of multiple linear regression analysis, it was established that directive leadership style had a positive and significant relationship with employee job satisfaction, $R 2=.228, F(1,362)=53.396, p<.05 ; \beta=.454, p<.05$. The results from multiple linear regression analysis also showed that supportive leadership style positively and significantly predicted employee job satisfaction, $R 2=.603, F(1,366)=278.269, p<$ $.05 ; \beta=.716, p<.05$. In addition, the study tested the moderating influence of environmental contingency factors and was confirmed that environmental contingency factors significantly moderated the relationship between path-goal leadership style and employee job satisfaction, $R 2=0.090, F(5,364)=35.04, p<.05 ; \beta=0.229, p<.05$.

The study makes a contribution to the literature of the influence of directive and supportive leadership styles from Kenyan commercial banks' perspective and adds an impetus to employees, management and policymakers to address issues that are impeding employee job satisfaction. The future researchers should include all bank employees in their study to determine the influence of directive leadership style and supportive leadership style on employee job satisfaction.
\end{abstract}


Keywords: Directive Leadership, Supportive Leadership, Path-Goal Leadership Styles, Employee Job Satisfaction.

Received: 6 August 2019;

Accepted: 3 October 2019 ;

Publish; December 2019.

\section{How to Cite:}

Mwaisaka, D., K'aol, G, M.R, \& Ouma, C. (2019). Influence of Supportive and Directive Leadership Styles on Employee Job Satisfaction in Commercial Banks in Kenya. International Journal of Human Capital Management, 3 (2), 42-60. https://doi.org/10.21009/IJHCM.03.02.05

\section{INTRODUCTION}

Path-goal theory makes a provision for the personal behaviour in a certain method based on the expectation that the behaviour creates certain results that are attractive to the given individual. Northouse (2013) posited that the development of path-goal theory was meant to encourage organizational leadership and inculcate their support of the followers in achievement of organization goals through creating an easy and clear path of achievement of the targeted objectives. It was also meant to make a clarification on the path that leadership should follow in achieving organization goals through the workers. It was further meant to remove roadblocks that prevent the leadership of organizations in achieving the set objectives through increasing the rewards as a motivation to attaining the set targets. Employee job satisfaction usually lean on the ability of the leadership to provide the clarity and leadership required to effectively achieve organization goals.

Hughes (2016) argued that the duty of the leadership as defined by path goal model is aimed at enhancing employees' confidence that they are capable of achieving the objectives set for them and that once that is done, they will receive the right reward from their organization. It is hence the prerogative of the manager to ensure employees develop a sense of self efficacy and a realization of consequent rewards (Northouse, 2013). The leadership of the organization has the onus to guide the employees to successfully pursue the achievement of the organization goals. Additionally, the organization leadership should assist the employees to solve problems that they may encounter in the workplace.

To inculcate an atmosphere of satisfied employee in the workplace, there is the necessity in establishing the strength of association between the leadership style in use by the managers and level of satisfaction enjoyed by the employees. This then provides the basis for carrying out the study to determine how directive leadership style and supportive leadership style influence employee job satisfaction.

\section{a. Problem Statement}

Globally, the aspect of job satisfaction among employees is highly illuminated as a result of the intense competition arising from globalization and technological advancement. Among financial institutions, employee job satisfaction is a major determinant of the survival, demise and growth of the organization. Financial institutions where employees are satisfied with the workplace have witnessed rapid growth and expansion, despite the existing challenges. In an organizational setting, employee job satisfaction is considered crucial as it is one of the parameters that determine the success of an organization (Ludviga \& Kalvina, 2016). Famakin and Abisuga (2016) stated that path-goal leadership style influences the commitment and levels of satisfaction of employees. Famakin and Abisuga further added that only $20 \%$ of managers in commercial banks in developing economies have embraced leadership styles under the umbrella of path-goal theory in the context of their operations. However, little empirical evidence has been undertaken to assess the Kenyan context. 
Many leadership scholars, (Ludviga \& Kalvina, 2016; Famakin \& Abisuga, 2016; Salanova \& Sanni, 2016; Hearthfield, 2012) have conducted studies on the relationships between path-goal theory and employee job satisfaction. However, Kagwiria (2016) found that a few studies have focused on use of path-goal leadership style in financial organizations. Abu-Shamaa, Al-Rabayah and Khasawneh (2016) stated that most research has focused on relating job satisfaction and performance in public and private organizations. Redmond and Serrano (2015) confirmed that studies on leadership styles have concentrated on participatory leadership style, work attitudes and employee motivation with few focusing on path-goal leadership style and job satisfaction. Alanazi (2013) study on the influence of path-goal leadership theory concurred that a shortage of empirical literature exists especially on the association of path-goal leadership styles and job satisfaction of employees.

\section{b. Purpose of the Study}

The purpose of the study was to establish the influence of directive and supportive leadership style on employee job satisfaction in commercial banks in Kenya.

\section{c. Research Questions}

The study was guided by the subsequent questions:

1. How does directive leadership style influence employee job satisfaction in commercial banks in Kenya?

2. How does supportive leadership style influence employee job satisfaction in commercial banks in Kenya?

3. How do environmental contingency factors moderate the relationship between pathgoal leadership styles and employee job satisfaction in commercial banks in Kenya?

The study was guided by the subsequent null hypotheses:

$\mathbf{H}_{\mathbf{0 1}}$ : There is no significant influence of directive leadership style on employee job satisfaction in commercial banks in Kenya.

$\mathbf{H}_{\mathbf{0 2}}$ : There is no significant influence of supportive leadership style on employee job satisfaction in commercial banks in Kenya.

$\mathbf{H}_{\mathbf{0 3}}$ : Environmental contingency factors do not have significant moderating influence on the relationship between path-goal leadership styles and employee job satisfaction.

\section{LITERATURE REVIEW}

\section{a. Theoretical Review}

The study was based on path-goal leadership theory. House and Mitchell (1974) stated that leader behavior refers to the expected code of conduct exhibited by people in power. The leaders provide the expected performance levels, and acceptable means through which those following the leader should use to attain the specified goals. There are four varieties of leadership behaviour and styles postulated: Directive, Supportive, Participative, and Achievement-oriented. Gustafsson and Hornay (2014) state that path-goal leadership styles are the leadership styles pathways model provides. A leader characterized as directive will give his followers detailed instructions on the tasks, the anticipated level of performance, time frames and stringent rules and regulations to observe.

A supportive leader is presented as warm, friendly, and available to his subordinates. He provides a work environment that facilitates the best out of the other employees, shows clear concern for the well-being of the subordinates, and is highly respectful to them. The leader seeks the opinions of the followers and puts them into consideration while making key decisions (Famakin \& Abisuga, 2016). An Achievement oriented leader is more results focused. He challenges those following him to give the best of them in performance. He demonstrates his confidence to employees in their capacity to deliver on challenging duties 
and goals (Northouse, 2013). This means that leadership style need not be applied singularly but rather they could be interchanged depending on the circumstances.

\section{b. Conceptual Framework}

Independent Variable

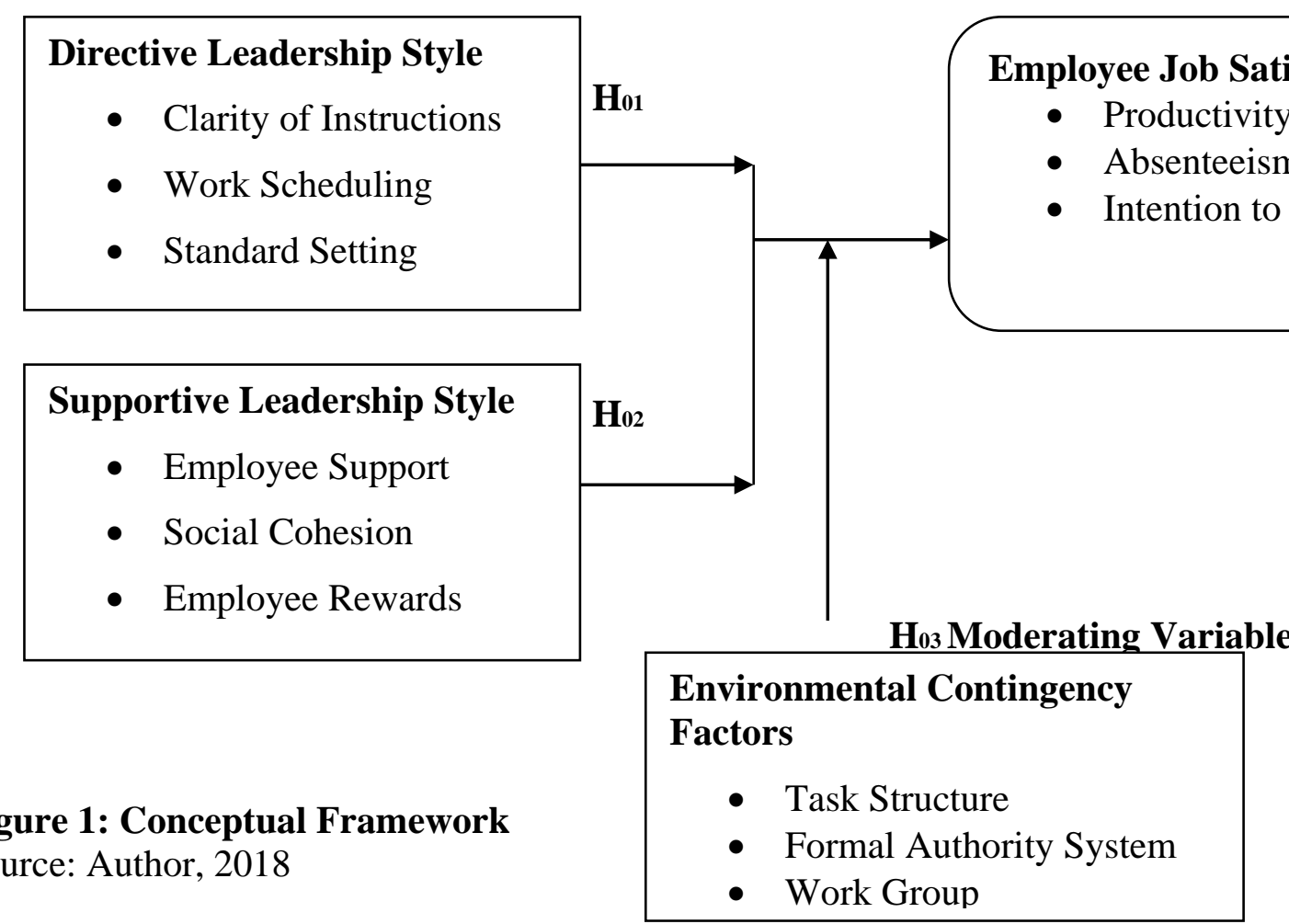

A conceptual framework is a tool for analysis that provides the context of how different variables under study interact (Abend, 2013).

The conceptual framework for this study comprises of the independent variables as directive leadership style and supportive leadership style. The dependent variable is employee job satisfaction amongst employees and the moderating variable is environmental contingency factors. The conceptual framework is shown in Figure 1.

\section{c. Empirical Review}

This section provides a short discussion of studies conducted on the recent past on directive leadership, supportive leadership and employee job satisfaction. The research questions in chapter one guides how this section is structured.

\section{Directive Leadership Style and Employee Job Satisfaction}

Job satisfaction among employee is highly influenced by the leadership style they are subjected to. Directive leadership is characterized by high use of authority and legitimate power. The leadership is highly instructional, supervision is close and commands are expected to be followed to the letter (Northouse, 2010). The standards of performance are clearly outlined and rules and regulations well stipulated. The timeframes on all activities are well communicated and an expectation is heavily sensed that they should be strictly adhered to. Directive leaders have clear performance standards, provides very strict directions and instructions that an employee must adhere with in doing the assigned task (Casson \& Farmer, 2014).

Directive leadership is most desirable if the tasks expected to be done by employees are not well defined (Yoder \& Staudohor, 2014). It is also appropriate when there are huge uncertainties in the work environment. Directive leadership clearly stipulates what is expected of an employee, reducing variation in interpretation of the instructions. An employee is made to understand early on what the relationship between performance and 
rewards are (Brown, 2016). Directive leadership has been seen as highly aggressive and controlling. It is dictatorial in nature with compliance being out of coercion more than will. Research shows that the directive leadership style has been seen to frustrate employee's satisfaction at work (Yun, Cox \& Sims, 2017). Nonetheless those whose tasks are simple and clear, directive leadership kill their motivation to work (Leakey, 2012).

Riffat-un-NisaAwan and Bigger (2013) studied leadership behaviors of Degree College principals' and job expectancies in Punjab, Pakistan. The study found that directive leadership resulted to low job satisfaction. According to Hemakumara (2012), a major reason for sluggish organizational response, slow strategic decision making and slow organizational growth in India has been excessive application of directive leadership in business organizations. The leaders are highly instructional making entire work forces reliant on a small group of leaders. The employee's minds are closed in following what the leader instructs and will hardly go beyond their expected performance levels even when they can. The work environment becomes highly mechanistic full of repetitive tasks (Bligh \& Hatch, 2014).

\section{Supportive Leadership Style and Employee Job Satisfaction}

Organizations require formulating work environment where employees have a team work and cohesiveness in the work place. This will enhance job satisfaction and organizational productivity (Qureshi \& Sajjad, 2015). Supportive leadership provides a friendly work environment, attends to the general well-being of employees (Northouse, 2013). Both physical and psychological needs of the employees are put into consideration which results into a satisfying work environment. The elements of supportive leadership style discussed in this section are; employee support, social cohesion, employee rewards and employee engagement.

Supportive leadership is highly recommended when the tasks assigned to employees are highly stressful or frustrating. Research proves that when an employee perceives he is supported by other employees and management, they perform better (Rahman et al., 2015). This has been seen to reflect in organizational profitability (Bhatia, 2013). This kind of leadership has been recommended in circumstances where formal authority in an organization is not strong and the work group is not very supportive or inspiring (Lussier \& Achua, 2010).

According to Shafritz (2010), when the leaders and subordinates relate well, job satisfaction is enhanced. It is not an expensive venture to create a social environment in the work place that is conducive for friendliness which is seen to improve performance of individual employees and organization at large (Onimole, 2015). The leaders need to embrace values and ideals that are facilitative of such an environment. They should lead from the front (Jit, 2013). Sinek (2014), reasons that the leader should spend more time with employees regard them highly let them enjoy their work and most importantly, place them first.

Supportive leadership influences how an employee perceives their job (Macey \& Shneider, 2014). When leaders are seen to be fair and acknowledge good performance, the employees are more enthusiastic at the work place. This relates to the employees commitment and competence. Employees develop confidence in their leaders which enhances their work devotion. Supportive leaders recognize individual interests of employees and help them reconcile that with the objectives of the organization (Monyazi, 2015). The employees eventually connect with shared vision of the organization which makes them see their contribution to it more meaningful. Employees develop a greater sense of self-esteem and high self-concept. Research shows that supportive leadership is facilitative of employee attachment to their jobs (Smit, 2016).

\section{Environmental Contingency Factors and Employee Job Satisfaction}

Malik (2013) stated that task structure, work group and formal authority are the three categories of environmental contingency factors. Temple (2013) study examined the job satisfaction of information technology and the effects of such a structure in financial sectors 
in USA. Organizational structure influences level of motivation and satisfaction of employees. It also had a correlation with employees reward systems in an organization. Structures influenced employee's autonomy, and pathways to objective delivery. Elangovan (2017) studied on the association between task orientation, performance and job satisfaction amongst public organizations employees. When employees are satisfied with the job, they perform their duties with greater excellence. There was relationship between level of supervision and job performance. Tomazević, Seljak and Aristovnik (2014) examined factors influencing job satisfaction in police force. It was observed education levels of management and employees significantly influenced the satisfaction levels of the customers.

Ganguly (2015) study investigated composition in work groups in terms of gender influenced employee's satisfaction at work in USA. The findings were that job satisfaction is related to the gender composition of employees in a given work group. However, there were no variations existing among male and female respondents on how the composition affected their satisfaction. Where the groups had gender balance there was greater job satisfaction across genders. Lowest satisfaction was noted in groups dominated by men while groups dominated by women were only averagely satisfied with their jobs.

\section{METHODOLOGY}

Positivism was the research philosophy adopted to guide this study. Positivism is used to support the testing of hypotheses and this is the key reason the philosophy was preferred. The population of the study consisted of 15,030 employees. A sample size of 386 was drawn using stratified random sampling. Data was collected using self-administered questionnaires. The data was then analyzed using descriptive statistics of frequency and percentage distribution, mean, and standard deviation. Additionally, inferential data analysis methods were used. These include: factor analysis, Pearson's correlation, ANOVA, and multiple linear regression that were used to test the hypotheses.

\section{RESULT AND DISCUSSION}

This chapter presents the results and findings of the data analyzed and presented in different sections systematically as guided by the research questions. Demographic information of the respondents, directive leadership style, supportive leadership style and environmental contingency factors are presented in this order. A total of 389 questionnaires were distributed and 370 questionnaires returned representing a response rate of $95 \%$.

\section{A. Demographic Information}

The demographic information of the respondents analyzed included gender of respondents, length of service and level of education. 
Table 1: Demographic Results

\begin{tabular}{|l|l|}
\hline Demographic Variables & Results \\
\hline Gender of respondents & Male =52\% \\
& Female =48\% \\
\hline Work Experience of the respondents & $0-1$ years $=11 \%$ \\
& $1-5$ years $=28 \%$ \\
& $5-10$ years =39\% \\
& Over 10 years =21\% \\
\hline Level of Education of respondents & Certificate =2\% \\
& Diploma =4\% \\
& Undergraduate $=91 \%$ \\
& Masters $=3 \%$ \\
\hline
\end{tabular}

\section{B. Directive Leadership \\ 1. Descriptive Statistics}

Descriptive statistical analysis conducted by the study included mean and standard deviation. The results in Table 2 indicates that on average, the supervisor schedules the tasks and duties that employees required to perform $(M=3.35, S D=0.973)$. It was found that employees' productivity on the job has improved because the supervisors give clear instructions for tasks and duties that employees are required to perform $(M=2.74, S D=0.938)$.

Table 2: Mean and Standard Deviation for Directive Leadership Style

\begin{tabular}{|l|l|l|l|l|}
\hline Directive Leadership & $\mathbf{N}$ & $\mathbf{M}$ & \multicolumn{1}{|l|}{ SD } \\
\hline $\begin{array}{l}\text { My team leader/supervisor gives clear instructions for every task and duty } \\
\text { given }\end{array}$ & 370 & 2.70 & 1.056 \\
\hline $\begin{array}{l}\text { My team leader/supervisor schedules the tasks and duties that I am } \\
\text { required to perform }\end{array}$ & 370 & 3.35 & .973 \\
\hline $\begin{array}{l}\text { My team leader/supervisor sets standard of performance for tasks and } \\
\text { duties that I am required to perform }\end{array}$ & 368 & 2.76 & 1.066 \\
\hline Influence of Directive Leadership on Employee Job Satisfaction & 370 & 2.74 & .938 \\
\hline $\begin{array}{l}\text { My productivity on the job has improved because my team } \\
\text { leader/supervisor gives clear instructions for tasks and duties that I am } \\
\text { required to perform }\end{array}$ & 370 \\
$\begin{array}{l}\text { I am rarely absent from work because my team leader/supervisor } \\
\text { schedules tasks and duties that I am required to perform }\end{array}$ & 370 & 2.44 & 1.107 \\
\hline $\begin{array}{l}\text { I do not intend to leave the organization because my team } \\
\text { leader/supervisor sets performance standard for tasks and duties that I am } \\
\text { require to perform }\end{array}$ & 370 & 2.36 & 1.328 \\
\hline
\end{tabular}

\section{Correlation between Directive Leadership and Employee Job Satisfaction}

Correlation refers to a quantitative estimation of the oscillation of two variables with each other. The increase or decrease of two variables in parallel leads to a positive correlation. However, in case one variable increases and the other decreases, then the correlation is negative. In this study, correlation analysis was undertaken to measure the strength of the linear association between the independent and dependent variables. Usually, the Pearson Correlation Coefficient, $r$ values range from +1 to -1 , that is coefficient $r$ may portray either a positive or negative relationship. Table 3 presents the correlation coefficients between study variables. The results show that there was a positive significant correlation coefficient between directive leadership style and employee job satisfaction among middle level managers of commercial banks in Kenya, $\mathrm{r}(370)=.779, p<.05$.

Table 3: Correlation Analysis for Directive Leadership Style 


\begin{tabular}{|l|l|l|l|}
\hline \multirow{5}{*}{ Directive Leadership Style } & Pearson Correlation & 1 & $.779^{* *}$ \\
\cline { 2 - 4 } & Sig. (2-tailed) & & .000 \\
\cline { 2 - 4 } & $\mathrm{N}$ & 370 & 370 \\
\hline Employee Job Satisfaction & Pearson Correlation & $.779^{* *}$ & 1 \\
\cline { 2 - 4 } & Sig. (2-tailed) & .000 & 370 \\
\cline { 2 - 4 } & $\mathrm{N}$ & 370 & \\
\hline *. Correlation is significant at the & 0.05 level (2-tailed).
\end{tabular}

\section{Regression Analysis and Hypothesis Testing}

Multiple linear regression analysis is conducted to examine whether one or more independent/predictor variables cause changes in the dependent variable. A multiple regression analysis was conducted to demonstrate the relationship between the independent variable (directive leadership style) and the dependent variable (employee job satisfaction). Based on a multiple linear regression model, the study sought to determine the influence of directive leadership style on employee job satisfaction among the middle level managers in Kenyan commercial banks. Therefore, the hypothesis tested was:

H0$_{1}$ : Directive leadership style has no significant influence on employee job satisfaction among middle level managers in commercial banks on Kenya.

The results from regression model summary explain the variations in dependent variable as a result of independent variable. The results in Table 4 show that directive leadership style caused a variation of $22.8 \%$ in employee job satisfaction among the middle level managers of commercial banks in Kenya, $\mathrm{R}^{2}=.228$. This means that when directive leadership style is applied in commercial banks in Kenya, 22.8\% variations in employee job satisfaction among the middle level managers in commercial banks in Kenya could be caused by directive leadership style.

Table 4: Regression Model Summary for Directive Leadership Style

\begin{tabular}{|c|c|c|c|c|c|c|c|c|c|c|}
\hline \multirow[t]{3}{*}{ Model I } & \multirow[t]{3}{*}{$\mathbf{R}$} & \multirow{3}{*}{$\begin{array}{l}\text { R } \\
\text { Square }\end{array}$} & \multirow{3}{*}{\begin{tabular}{|l} 
Adjusted \\
R Square
\end{tabular}} & \multicolumn{3}{|c|}{ Std. ErrorChange Statistics } & \multirow{3}{*}{ df1 } & \multirow{3}{*}{ df2 } & \multirow{3}{*}{$\begin{array}{l}\text { Sig. } \\
\text { Change }\end{array}$} & \\
\hline & & & & of the & $\mathbf{R} \quad \mathrm{Squ}$ & & & & & \\
\hline & & & & estimate & Change & Change & & & & \\
\hline 1 & $.477^{\mathrm{a}}$ & 228 & 224 & .83927192 & .228 & 53.396 & 1 & 362 & .000 & \\
\hline 2 & $.554^{\mathrm{b}}$ & 307 & 299 & .79726460 & .079 & 20.576 & 1 & 360 & .000 & \\
\hline
\end{tabular}

The study results in Table 5 demonstrate that the relationship between directive leadership style and employee job satisfaction among middle level managers in commercial banks was significant, $F(1,362)=53.396, p<.05$. These findings implied that the overall model was significant in associating directive leadership style and employee job satisfaction among the managers of commercial banks. The findings also demonstrated that directive leadership style was a good predictor of employee job satisfaction among the middle level managers in the commercial banks of Kenya. The study hence concluded that the model was significant in explaining the relationship between the independent variable (directive leadership style) and the dependent variable (employee job satisfaction). Considering the significance of the $F$-statistic, the null hypothesis, directive leadership style has no significant influence on employee job satisfaction among middle level managers of Kenyan commercial banks, was rejected.

Table 5: Regression ANOVA for Directive Leadership Style

\begin{tabular}{|l|l|l|l|l|l|l|}
\hline \multicolumn{2}{|l}{ Model } & Sum of Squares & Df & Mean Square & F & Sig. \\
\hline \multirow{3}{*}{1} & Regression & 37.611 & 1 & 37.611 & 53.396 & $.000^{\mathrm{b}}$ \\
\cline { 2 - 8 } & Residual & 127.492 & 362 & .704 & & \\
\cline { 2 - 8 } & Total & 165.103 & 364 & & & \\
\hline
\end{tabular}


Regression coefficient refers to the slope as indicated by the linear relationship between the independent and the dependent variables. Multiple linear regression was carried out with an aim of examining the magnitude and direction of the relationship between directive leadership and employee job satisfaction. The study findings confirmed that directive leadership style significantly predicted employee job satisfaction among middle level managers in the commercial banks of Kenya, $\beta=.454, t(370)=7.307, p<.05$. This implied that a unit change in directive leadership style would lead to an increase in employee job satisfaction among the middle level managers by 0.454 units. As a result, the study concluded that directive leadership style significantly predicts employee job satisfaction among middle level managers in the commercial banks of Kenya. Table 6 presents the study results.

Table 6: Regressions Coefficient for Directive Leadership Style

\begin{tabular}{|c|c|c|c|c|c|c|}
\hline \multirow{2}{*}{\multicolumn{2}{|c|}{ Model }} & \multicolumn{2}{|c|}{$\begin{array}{l}\text { Unstandardized } \\
\text { Coefficients }\end{array}$} & \multirow{2}{*}{\begin{tabular}{|c|}
$\begin{array}{l}\text { Standardized } \\
\text { Coefficients }\end{array}$ \\
Beta \\
\end{tabular}} & \multirow[t]{2}{*}{$\mathbf{T}$} & \multirow[t]{2}{*}{ Sig. } \\
\hline & & $\mathbf{B}$ & Std. Error & & & \\
\hline \multirow{2}{*}{1} & (Constant) & .107 & .042 & & 2.548 & .012 \\
\hline & Direct leadership & .454 & .062 & .477 & 7.307 & .000 \\
\hline & (Constant) & .110 & .049 & & 2.245 & .026 \\
\hline & Direct leadership & .289 & .069 & .304 & 4.173 & .000 \\
\hline & $\begin{array}{l}\text { Environmental contingency } \\
\text { factors X Direct leadership }\end{array}$ & 315 & .070 & .330 & 4.536 & .000 \\
\hline
\end{tabular}

\section{B. Supportive Leadership Style}

\section{Descriptive Statistics}

Descriptive statistical analysis conducted by the study included mean and standard deviation. The results demonstrate that on average, the supervisor maintains a friendly working relationship with the team members $(M=2.55, S D=.983)$. It was found that employees are rarely absent from work because the supervisor maintains a friendly working relationship with the team members $(M=2.52, S D=0.944)$.

Table 7: Mean and Standard Deviation for Supportive Leadership Style

\begin{tabular}{|l|l|l|l|}
\hline Supportive Leadership & $\mathbf{N}$ & $\mathbf{M}$ & SD \\
\hline $\begin{array}{l}\text { My team leader/supervisor helps me to overcome problems that can } \\
\text { prevent me from carrying out my duties and tasks }\end{array}$ & 370 & 2.29 & 1.229 \\
\hline $\begin{array}{l}\text { My team leader/supervisor maintains a friendly working relationship } \\
\text { with the team members }\end{array}$ & 370 & 2.55 & .983 \\
\hline $\begin{array}{l}\text { My team leader/supervisor gives encouragement and rewards for the } \\
\text { duties and tasks that I have done well }\end{array}$ & 370 & 2.77 & 1.149 \\
\hline Influence of Supportive Leadership on Employee Job Satisfaction & & \\
\hline $\begin{array}{l}\text { My productivity on the job has improved because my team } \\
\text { leaders/supervisor helps me to overcome problems that can prevents } \\
\text { me from carrying out my duties and tasks }\end{array}$ & 370 & 2.91 & 1.080 \\
\hline $\begin{array}{l}\text { I am rarely absent from work because my team leader/supervisor } \\
\text { maintains a friendly working relationship with the team members }\end{array}$ & 370 & 2.52 & .944 \\
\hline
\end{tabular}


I do not intend to leave the organization because my team leader/supervisor gives encouragement and rewards for the duties and tasks that I have done well

\section{Correlation between Supportive Leadership Influence on Employee Job Satisfaction}

Correlation refers to a quantitative estimation of the oscillation of two variables with each other. The increase or decrease of two variables in parallel leads to a positive correlation. However, in case one variable increases and the other decreases, then the correlation is negative. In this study, correlation analysis was undertaken to measure the strength of the linear association between the independent and dependent variables. Usually, the Pearson Correlation Coefficient, $r$ values range from +1 to -1 , that is coefficient $r$ may portray either a positive or negative relationship.

Table 8: Correlation Analysis for Supportive Leadership Style

\begin{tabular}{|l|l|l|l|}
\hline \multicolumn{3}{|l|}{ Correlations } \\
\hline $\begin{array}{l}\text { Supportive } \\
\text { Satisfaction }\end{array}$ & Leadership and Job & $\begin{array}{l}\text { Supportive } \\
\text { Leadership Style }\end{array}$ & $\begin{array}{l}\text { Employee } \\
\text { Satisfaction }\end{array}$ \\
\hline $\begin{array}{l}\text { Supportive } \\
\text { Leadership Style }\end{array}$ & Pearson Correlation & 1 & $.816^{* * *}$ \\
\cline { 2 - 4 } & Sig. (2-tailed) & & .000 \\
\cline { 2 - 4 } & $\mathrm{N}$ & 370 & 370 \\
\hline $\begin{array}{l}\text { Employee Job } \\
\text { Satisfaction }\end{array}$ & Pearson Correlation & $.816^{* *}$ & 1 \\
\cline { 2 - 4 } & Sig. (2-tailed) & .000 & 370 \\
\cline { 2 - 4 } & $\mathrm{N}$ & 370 & \\
\hline * Correlation is significant at the 0.05 level (2-tailed). & \\
\hline
\end{tabular}

Table 8 presents the correlation coefficients between study variables. The results show a positive and significant correlation coefficient between supportive leadership style and employee job satisfaction $r(370)=0.816, p<.05$.

\section{Regression Analysis and Hypothesis Testing}

Multiple linear regression analysis is conducted to examine whether one or more independent/predictor variables cause changes in the dependent variable. A multiple regression analysis was conducted to demonstrate the relationship between the independent variable (directive leadership style) and the dependent variable (employee job satisfaction). Based on a multiple linear regression model, the study sought to determine the influence of directive leadership style on employee job satisfaction among the middle level managers in Kenyan commercial banks. Therefore, the hypothesis tested was:

$\mathbf{H O}_{2}$ : Supportive leadership style has no significant influence on employee job satisfaction among middle level managers in commercial banks on Kenya.

The results from regression model summary explain the variations in dependent variable as a result of independent variable. The results in Table 9 show that supportive leadership style caused a variation of about sixty percent (60.3\%) in employee job satisfaction among the middle level managers of commercial banks in Kenya, $\mathrm{R}^{2}=.603$. This means that when supportive leadership style is applied in commercial banks in Kenya, 60.3\% variations in employee job satisfaction among the middle level managers in commercial banks in Kenya could be established

Table 9: Regression Model Summary for Supportive Leadership Style 


\begin{tabular}{|c|c|c|c|c|c|c|c|c|c|}
\hline \multirow[t]{3}{*}{ Model } & \multirow[t]{3}{*}{$\mathbf{R}$} & \multirow{3}{*}{$\begin{array}{l}\text { R } \\
\text { Square }\end{array}$} & \multicolumn{4}{|c|}{ Adjusted Std. Error Change Statistics } & \multirow{3}{*}{ df1 } & \multirow{3}{*}{ df2 } & \multirow{3}{*}{$\begin{array}{l}\text { Sig. I } \\
\text { Change }\end{array}$} \\
\hline & & & R Square & & e Squal & $\mathbf{F}$ & & & \\
\hline & & & & Estimate & Change & Change & & & \\
\hline 1 & $.777^{\mathrm{a}}$ & .603 & 601 & .58218649 & 603 & 278.269 & 1 & 366 & .000 \\
\hline 2 & $.793^{b}$ & .629 & .625 & .56463281 & .026 & 12.555 & 1 & 364 & .001 \\
\hline
\end{tabular}

The study results in Table 10 indicate that the relationship between supportive leadership style and employee job satisfaction among middle level managers in commercial banks was significant, $F(1,366)=278.269, p<.05$. These findings implied that the overall model was significant in associating supportive leadership style and employee job satisfaction among the managers of commercial banks. The findings also demonstrated that supportive leadership style was a good predictor of employee job satisfaction among the middle level managers in the commercial banks of Kenya. The study hence concluded that the model was significant in explaining the relationship between the independent variable (supportive leadership style) and the dependent variable (employee job satisfaction). Considering the significance of the $F$-statistic, the null hypothesis, supportive leadership style has no significant influence on employee job satisfaction among middle level managers of Kenyan commercial banks, was rejected.

Table 10: ANOVA Test for Supportive Leadership Style

\begin{tabular}{|l|l|l|l|l|l|l|}
\hline \multicolumn{2}{|l}{ Model } & Sum of Squares & Df & Mean Square & F & Sig. \\
\hline \multirow{3}{*}{1} & Regression & 94.317 & 1 & 94.317 & 278.269 & $.000^{\mathrm{b}}$ \\
\cline { 2 - 8 } & Residual & 62.026 & 366 & .339 & & \\
\cline { 2 - 8 } & Total & 156.343 & 368 & & & \\
\hline
\end{tabular}

Regression coefficient refers to the slope as indicated by the linear relationship between the independent and the dependent variables. Multiple linear regression was conducted to examine the magnitude and direction of the relationship between supportive leadership and employee job satisfaction. The study findings confirmed that supportive leadership style significantly predicted employee job satisfaction among middle level managers in the commercial banks of Kenya, $\beta=.716, t(370)=16.681, p<.05$. This implied that a unit change in supportive leadership style would lead to an increase in employee job satisfaction among the middle level managers in the banking industry by 0.716 units. As a result, the study concluded that supportive leadership style significantly predicts employee job satisfaction among middle level managers in the commercial banks of Kenya. Table 11 presents the study results.

Table 11: Regression Coefficients for Supportive Leadership Style

\begin{tabular}{|c|c|c|c|c|c|c|}
\hline \multirow{2}{*}{\multicolumn{2}{|c|}{ Model }} & \multicolumn{2}{|c|}{$\begin{array}{l}\text { Unstandardized } \\
\text { Coefficients }\end{array}$} & \multirow{2}{*}{\begin{tabular}{|l|}
$\begin{array}{l}\text { Standardized } \\
\text { Coefficients }\end{array}$ \\
Beta \\
\end{tabular}} & \multirow[t]{2}{*}{$\mathbf{T}$} & \multirow[t]{2}{*}{ Sig. } \\
\hline & & $\mathrm{B}$ & Std. Error & & & \\
\hline \multirow{2}{*}{1} & (Constant) & .094 & .043 & & 2.198 & .029 \\
\hline & Supportive & .716 & .043 & .777 & 16.681 & .000 \\
\hline \multirow{3}{*}{2} & (Constant) & .082 & .037 & & 2.232 & .027 \\
\hline & Supportive & .690 & .042 & .748 & 16.323 & .000 \\
\hline & SLXECF & .145 & .041 & .162 & 3.543 & .001 \\
\hline
\end{tabular}

\section{c. Environmental Contingency Factors}

\section{Descriptive Statistics}

The study in this sub-section conducted descriptive analysis namely, mean, and standard deviation. 
The findings in Table 12 indicate that generally, the supervisor built a team of staff who worked on tasks together $(M=2.84, S D=1.035)$. The study results also show that employee productivity on the job had improved because their supervisor provided a detailed job description and procedures for their tasks and duties $(M=2.83, S D=.971)$.

\section{Table 12: Mean and Standard Deviation for Environmental Contingency Factors}

\begin{tabular}{|l|l|l|l|}
\hline Environmental Contingency Factors & $\mathbf{N}$ & $\mathbf{M}$ & SD \\
\hline $\begin{array}{l}\text { My team leader/supervisor provides a detailed job description and } \\
\text { procedures for my tasks and duties }\end{array}$ & 370 & 2.38 & 1.122 \\
\hline $\begin{array}{l}\text { My team leader/supervisor ensures there are processes in place that } \\
\text { enables me to carry out my tasks and duties without the need to consult } \\
\text { others }\end{array}$ & 370 & 2.36 & 1.044 \\
\hline $\begin{array}{l}\text { The team leader/supervisor builds a team of staff who work on tasks } \\
\text { together }\end{array}$ & 370 & 2.84 & 1.035 \\
\hline Influence of Environmental Contingency Factors on Employee Job Satisfaction & & \\
\hline $\begin{array}{l}\text { My productivity on the job has improved because my team } \\
\text { leader/supervisor provides a detailed job description and procedures for } \\
\text { my tasks and duties }\end{array}$ & 368 & 2.83 & .971 \\
\hline $\begin{array}{l}\text { I am rarely absent from work because my team leader/supervisor ensures } \\
\text { there are processes in place that enables me to carry out my tasks and } \\
\text { duties without the need to consult others }\end{array}$ & 368 & 2.53 & .862 \\
\hline $\begin{array}{l}\text { I do not intend to leave the organization because my team } \\
\text { leader/supervisor builds a team of staff who work on tasks together }\end{array}$ & 368 & 2.33 & 1.278 \\
\hline
\end{tabular}

\section{Correlation between Environmental Contingency Factors and Employee Job} Satisfaction

Correlation refers to a quantitative estimation of the oscillation of two variables with each other. The increase or decrease of two variables in parallel leads to a positive correlation. However, in case one variable increases and the other decreases, then the correlation is negative. In this study, correlation analysis was undertaken to measure the strength of the linear association between the independent and dependent variables. Usually, the Pearson Correlation Coefficient, $r$ values range from +1 to -1 , that is coefficient $r$ may portray either a positive or negative relationship.

Table 13: Correlation Test for Environmental Contingency Factors

\begin{tabular}{|l|l|l|l|}
\hline \multicolumn{4}{|l|}{ Correlations } \\
\hline $\begin{array}{l}\text { Environmental Contingency Factors and Job } \\
\text { Satisfaction }\end{array}$ & $\begin{array}{l}\text { Environmental } \\
\text { Contingency Factors }\end{array}$ & $\begin{array}{l}\text { Employee Job } \\
\text { Satisfaction }\end{array}$ \\
\hline $\begin{array}{l}\text { Environmental Contingency } \\
\text { Factors }\end{array}$ & Pearson Correlation & 1 & $.817^{* *}$ \\
\cline { 2 - 4 } & Sig. (2-tailed) & & .000 \\
\cline { 2 - 4 } & $\mathrm{N}$ & 370 & 370 \\
\hline \multirow{3}{*}{ Employee Job Satisfaction } & Pearson Correlation & $.817^{* *}$ & 1 \\
\cline { 2 - 4 } & Sig. (2-tailed) & .000 & 370 \\
\cline { 2 - 4 } & $\mathrm{N}$ & 370 & \\
\hline
\end{tabular}

* Correlation is significant at the 0.05 level (2-tailed).

Table 13 presents the correlation coefficients between study variables. The results showed that the there was a positive significant correlation coefficient between employee job satisfaction and environmental contingency factors $r(370)=0.817, p<.05$.

\section{Regression Analysis and Hypothesis Testing}

The study sought to establish the moderating influence of environmental contingency factors on the relationship between path-goal leadership styles and job satisfaction of middle level managers at commercial banks in Kenya. The hypothesis tested was: 
$\mathbf{H}_{\mathbf{0 5}}$ : Environmental contingency factors do not have a significant moderating influence on the relationship between path-goal leadership styles and employee job satisfaction.

The results from regression model summary explain the variations in dependent variable as a result of independent variable. The results in Table 14 show that environmental contingency factors caused a variation of $9 \%$ in moderating the relationship between path-goal leadership styles and employee job satisfaction among the middle level managers of commercial banks in Kenya, $\mathrm{R}^{2}=.090$. This implies that when environmental contingency factors are applied in commercial banks in Kenya, 9\% variations in moderation of relationship between path-goal leadership styles and employee job satisfaction among the middle level managers in commercial banks in Kenya could be observed.

Table 14: Regression Model after Moderation

\begin{tabular}{|c|c|c|c|c|c|c|c|c|c|}
\hline \multirow[b]{2}{*}{ Model } & \multirow[b]{2}{*}{$\mathrm{R}$} & \multirow[b]{2}{*}{$\begin{array}{l}\mathrm{R} \\
\text { Square }\end{array}$} & \multirow[b]{2}{*}{$\begin{array}{l}\text { Adjusted } \\
\mathrm{R} \\
\text { Square }\end{array}$} & \multirow{2}{*}{$\begin{array}{l}\text { Std. } \\
\text { Error of } \\
\text { the } \\
\text { Estimate }\end{array}$} & \multicolumn{5}{|c|}{ Change Statistics } \\
\hline & & & & & $\begin{array}{l}\mathrm{R} \\
\text { Square } \\
\text { Change }\end{array}$ & $\begin{array}{l}\text { F } \\
\text { Change }\end{array}$ & df1 & $\mathrm{df} 2$ & $\begin{array}{l}\text { Sig. F } \\
\text { Change }\end{array}$ \\
\hline 1 & $.853^{\mathrm{a}}$ & .799 & .761 & .587 & .799 & 3057.504 & 4 & 365 & .000 \\
\hline 2 & $.942^{\mathrm{b}}$ & .889 & .850 & .358 & .090 & 3167.117 & 1 & 364 & 0.000 \\
\hline
\end{tabular}

a. Predictors: (Constant), Achievement-Oriented Leadership Style, Directive Leadership Style, Participative Leadership Style, Supportive Leadership Style

b. Predictors: (Constant), Achievement-Oriented Leadership Style, Directive Leadership Style, Participative Leadership Style, Supportive Leadership Style, Environmental Contingency Factors

\section{Table 15: Regression ANOVA}

\begin{tabular}{|l|l|l|l|l|l|l|}
\hline \multicolumn{2}{|l|}{ Model } & Sum of Squares & Df & Mean Square & F & Sig. \\
\hline \multirow{3}{*}{1} & Regression & 107.311 & 4 & 26.828 & 30.57 & $.000^{\mathrm{b}}$ \\
\cline { 2 - 7 } & Residual & 3.203 & 365 & .009 & & \\
\cline { 2 - 7 } & Total & 110.514 & 369 & & & \\
\hline \multirow{2}{*}{2} & Regression & 110.514 & 5 & 22.103 & 35.04 & $.000^{\mathrm{c}}$ \\
\cline { 2 - 7 } & Residual & .000 & 364 & .000 & & \\
\cline { 2 - 7 } & Total & 110.514 & 369 & & & \\
\hline
\end{tabular}

a. Dependent Variable: Employee Job Satisfaction

b. Predictors: (Constant), Achievement-Oriented Leadership Style, Directive Leadership Style, Participative Leadership Style, Supportive Leadership Style

c. Predictors: (Constant), Achievement-Oriented Leadership Style, Directive Leadership Style, Participative Leadership Style, Supportive Leadership Style, Environmental Contingency Factors

The study results in Table 15 demonstrate that the moderating influence of environmental contingency factors between path-goal leadership style and employee job satisfaction among middle level managers in commercial banks was significant, $F(5,364)=$ $35.04, p<.05$. These findings implied that the overall model was significant in associating environmental contingency factors, path-goal leadership style and employee job satisfaction among the managers of commercial banks. The findings also demonstrated that environmental contingency factors were a good predictor of path-goal leadership styles and employee job satisfaction among the middle level managers in the commercial banks of Kenya. The study hence concluded that the model was significant in explaining the relationship between the independent variable (path-goal leadership styles) and the dependent variable (employee job satisfaction). Considering the significance of the $F$-statistic, the null hypothesis, the null hypothesis, environmental contingency factors do not have significant 
influence on the relationship between path-goal leadership styles and employee job satisfaction among middle level managers in commercial banks on Kenya, was rejected.

Regression coefficient refers to the slope as indicated by the linear relationship between the independent and the dependent variables. Multiple linear regression was conducted with an aim of examining how environmental contingency factors moderate the relationship between path-goal leadership styles and employee job satisfaction. The study findings confirmed that environmental contingency factors significantly moderate the relationship between path-goal leadership styles and employee job satisfaction among middle level managers in the commercial banks of Kenya, $\beta=0.229, t(370)=184.763$. The implication is that a unit increase in environmental contingency factors leads to an increase among the job satisfaction of employees by 0.419 units. As a result, the study concluded that environmental contingency factors significantly moderate the relationship between path-goal leadership styles and employee job satisfaction among middle level managers in the commercial banks of Kenya. Table 16 presents the study results.

Table 16: Regression coefficients

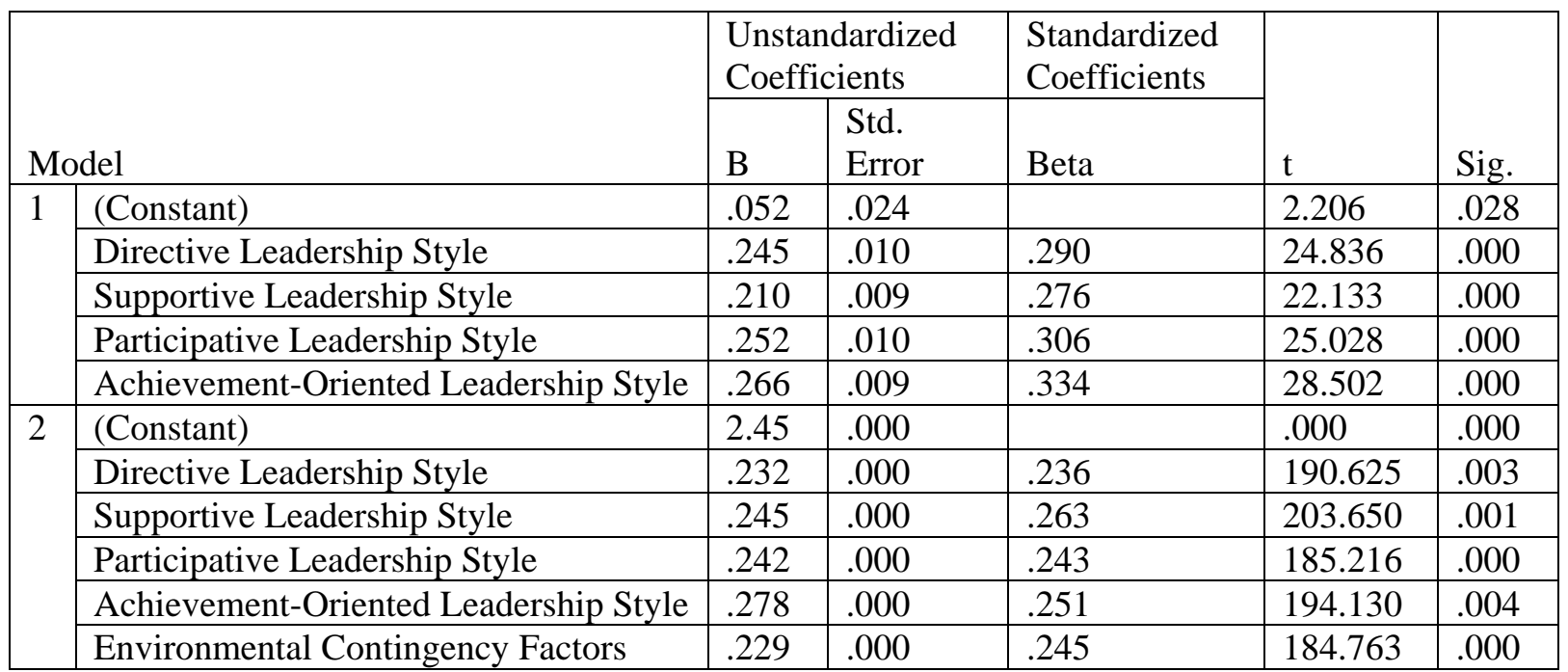

a. Dependent Variable: Employee Job Satisfaction

\section{Discussion of the Findings}

\section{Directive Leadership Style}

The study sought to establish the influence of directive leadership style on job satisfaction among middle level managers in commercial banks in Kenya. The findings from correlation analysis showed that directive leadership style positively and significantly relate to employee job satisfaction, $\mathrm{r}(370)=0.779, \mathrm{p}<.05$. The findings agree with Jones and George (2011) who observed that directive leaders set clear performance standards and procedures (Jones \& George, 2011). Robbins (2014) shared similar position saying that directive leaders provide strict guidance on the roles and tasks expected of their employees. This proves that directive leadership is about providing clear instructions in each and every task for performance of each task and this assists in employee job satisfaction in commercial banks.

There was a positive and significant correlation between job satisfaction and team leader/supervisor scheduling the tasks and duties that require to be performed $r(370)=0.638$, $p<.05$. The findings agree with Martin (2012) who pointed out that directive leadership demonstrates its greatest value when employees do not find clear clarity on what they are supposed to do at work or when the work environment is uncertain and unstable. Correlation coefficient between team leader/supervisor setting standard of performance for tasks and duties that require to be performed and job satisfaction was positive and significant $r(370)=$ $0.489, p<.05$. The findings support Dull (2010) who argued that a directive style makes it 
clear to employees on what and how they are expected to perform. The rewards employees should expect from their performance is made clear right from the start. The implication is that through directive leadership style, clarity of instructions and tasks performance is enhanced leading to employee job satisfaction in commercial banks.

\section{Supportive Leadership Style}

The study sought to establish the influence of supportive leadership style on job satisfaction among middle level managers in commercial banks in Kenya. From the findings, correlation analysis showed that supportive leadership style had a strong positive and significant relationship with employee job satisfaction, $\mathrm{r}(370)=0.816, \mathrm{p}<.05$. The findings support Lamb (2013) description of supportive leadership as one that focuses on developing positive relationships in order to improve employee job satisfaction. In addition, supportive leaders cultivate idea working environment and emotional support of employees. The study results showed that there was a positive significant correlation coefficient between employee job satisfaction and team leader/supervisor helping them to overcome problems that can prevent them from carrying out duties and tasks $r(370)=0.651, p<.05)$. Khuong and Dang (2015) research indicated that supportive leadership has two critical attributes; a supportive behavior to the employee work responsibilities and building a relationship with the employee themselves. Supporting the employee to the task is meant to build the employee confidence in doing their assigned duties.

There was a positive and significant correlation between employee job satisfaction and team leader/supervisor maintaining a friendly working relationship with the team members $(r=0.509, p<.05)$. Supportive leadership style is characterized by a leader who is friendly, approachable and treats employees as equals. Supportive leaders care about the cohesion of employees in the workplace and go out of their way to make the work more enjoyable for them (Lamb, 2013). The correlation coefficient between team leader/supervisor giving encouragement and rewards for the duties and tasks that they have done well and employee job satisfaction was positive and significant $(r=0.578, p<.05)$. Supportive leader puts emphasis wholesome needs of the employee are addressed. The employee growth needs are also considered (Malik, Aziz \& Hassan, 2014).

\section{Environmental Contingency Factors}

Environmental contingency factors were the moderating variable in this study. The correlation analysis showed that there prevailed a strong and positive relationship between environmental contingency factors and employee job satisfaction, $r(370)=.817, p<.05$. This agree with Northhouse (2013) that where uncertainties are present, environmental contingency factors such as formal authority system through achievement oriented, directive, supportive and participative leaders assist in enhancing employee job satisfaction.

The study revealed a significant correlation between task structure and employee job satisfaction, $r(370)=.505, p<.05$. A study by Temple (2013) confirmed that organizational structure influences level of motivation and satisfaction of employees. It also had a correlation with employees reward systems in an organization. Structures influenced employee's autonomy, and pathways to objective delivery. Elangovan (2017) studied on the association between task orientation, performance and job satisfaction amongst public organizations employees. When employees are satisfied with the job, they perform their duties with greater excellence. There was relationship between level of supervision and job performance. Tomazević, Seljak and Aristovnik (2014) examined factors influencing job satisfaction in police force. It was observed education levels of management and employees significantly influenced the satisfaction levels of the customers.

\section{CONCLUSION}

\section{Directive Leadership Style}

The study investigated and measured the influence of directive leadership style on employee job satisfaction among middle level managers in commercial banks in Kenya. The study 
results confirmed that directive leadership style positively and significantly predicted employee job satisfaction.

\section{Supportive Leadership Style}

The study sought to establish and measure the influence of supportive leadership style on employee job satisfaction among middle level managers in commercial banks in Kenya. The results from multiple linear regression analysis established that supportive leadership style positively and significantly predicted employee job satisfaction among middle level managers at commercial banks in Kenya.

\section{Moderating Influence of Environmental Contingency Factors}

The study established that environmental contingency factors significantly influenced the relationship between path-goal leadership style and employee job satisfaction among middle level managers in commercial banks in Kenya. The results from the multiple linear regression analysis revealed that environmental contingency factors significantly moderated the relationship between path-goal leadership style and employee job satisfaction among middle level managers in the commercial banks in Kenya.

\section{Recommendation for Improvement}

\section{Directive Leadership Style and Job Satisfaction}

The study confirmed a positive and significant relationship between directive leadership style and employee job satisfaction and concluded that directive leadership style significantly influences employee job satisfaction among middle level managers in commercial banks in Kenya. Commercial banks should use directive leadership style where employees do not have a clue of what they need to do to effectively to accomplish the goals and enhance their job satisfaction levels.

\section{Supportive Leadership Style on Employee Job Satisfaction}

The study established that there was a significant influence of supportive leadership style on job satisfaction of middle level managers in commercial banks in Kenya. This implied that developing positive relationships between the employer and employees in order to improve job satisfaction is crucial for a commercial bank. Management in commercial banks should improve job satisfaction by creating conducive working environment to foster respect, trust, cooperation and emotional support.

\section{Moderating Effect of Environmental Contingency Factors on Leadership Styles and Employee Job Satisfaction}

The study established that environmental contingency factors significantly influenced the relationship between path-goal leadership style and employee job satisfaction among middle level managers in commercial banks in Kenya. The management at commercial banks should encourage the use of environmental contingency factors like task structure, formal authority system and work group, when leading employees about an objective to be accomplished.

\subsection{Recommendation for Further Research}

The study determined the influence of path-goal leadership style on employee job satisfaction in commercial banks in Kenya. The study was limited to only commercial banks that operate in Kenya. As a result, the study recommends further researchers to examine the influence of path-goal leadership styles on employee job satisfaction in insurance companies, investment companies, and micro-finance institutions.

\section{REFERENCES}

Abend, G. (2013). The Meaning of Theory: Sociological Theory. San Francisco, CA: BerrettKoehler Publishers. 
Abu-Shamaa, R., Al-Rabayah, W., \& Khasawneh, R.T. (2016). The Effect of Job Satisfaction and Work Engagement on Organizational Commitment. The IUP Journal of Organizational Behavior, 4 (1), 1-5. https://doi:10.1007/s10551-014-2126-7.

Alanazi, E. (2013). Overview of path-goal leadership theory. Sains Humanika 64 (2), 1-2.

Bligh, M. C., \& Hatch, J. M. (2014). Psychological Issues in Organizational Culture. Wiley Periodicals, 1 (2), 35 - 53. https://doi: 10.1002/jpoc.21114.

Brown, D. R. (2016). An Experimental Approach to Organizational Development ( $8^{\text {th }}$ Ed). USA, Pearson Education.

Casson, R. J., \& Farmer, L. D. (2014). Understanding and checking the assumptions of linear regression: a primer for medical researchers. Clinical \& experimental ophthalmology, 42(6), 590-596. https://doi: 10.1111/ceo.12358.

Dubrin, A. (2015). Leadership: Research findings, practice, and skills. New York: Nelson Education Publishers.

Dull, M. (2010). Leadership and Organizational Culture: Sustaining Dialogue between Practitioners and Scholars. Public Administration Review, 857- 866. https://doi. org/10.1111/j.1540-6210.2010.02217.x.

Elangovan, A. R. (2017). Causal ordering of stress, satisfaction and commitment, and intention to quit: a structural equations analysis. Leadership \& Organization Development Journal, 22(4), 159-165. https://doi.org/10.1108/01437730110395051.

Famakin, I., \& Abisuga A. (2016). Effect of path-goal leadership styles on the commitment of employees on construction projects. International Journal of Construction Management, 16 (2)10-11. https://doi. org/10.1080/15623599.2015.1130601.

Ganguly R. (2015). Composition of work groups, Quality of work life and job satisfaction of employees in USA. Asian Journal of Management Research, 1 (8), 2229 - 3795. https://doi.org/ 10.11113/jt.v64.2235.

Gustafsson, J., \& Hornay. P. (2014). Leadership Driving Successful Implementation of Continuous Improvement Programs- A Case Study Using the Path Goal Model. Master Thesis, Technology Management-Nr 282/2015, University of Sweden.

Hart, P. (2011). Benefits of employee recognition in the workplace: reduced risk raised avenues. Journal of Management, 4(2), 49-52. https://doi.org/10.1080/02678370601065893

Hearthfield, S. M. (2012). Keys to Employee Satisfaction: What You Can Do to Increase Employee Satisfaction. World Applied Sciences Journal, 26 (10), 1304-1309. https://doi.org/10.5590/IJAMT.2017.16.1.04.

Hemakumara, N. (2012). Effective Leadership and Management. Colombo Journal of Commerce, 1 (2), 2-3. https://doi.org/10.5296/ijhrs.v9i2.14623.

House, R. J., \& Mitchell, T. R. (1974). Path-goal theory of leadership. Journal of Contemporary Business, Journal of Humanities, 3 (1) 1-97. https://doi.org/10.12691/education-5-7-2.

Hughes, L. (2016). Engaging Emergence: Turning Upheaval into Opportunity. Leadership \& Organizational Development Journal, $33 \quad$ (1), 105-106. https://doi.org/10.1109/JPROC.1997.628729.

Jha, S. (2014). Determinants of employee turnover intentions. Organization Development Journal, 2(1), 15-16. https://doi.org/10.1108/01437729410074182.

Jit, S. C. (2013). Organizational Behavior, ( $3^{\text {rd }}$ Ed.). VIKAS Publishing House, Reprint.

Jones, G. R., \& George, J. M. (2011). Essentials of Contemporary Management. Boston: McGraw-Hill.

Kagwiria, L., (2016). Influence of Leadership on Employee Productivity at KCB Bank Kenya Ltd. Nairobi Branches, University of Nairobi.

Khuong, M. N. \& Dang, T. H. (2015). The Effects of Leadership Styles on Employee Motivation in Auditing Organizations in Ho Chi Minh City, Vietnam, International Journal of Trade, Economics and Finance, 6 (7), 12-14. https://doi.org/10.19044/elp.v6no2a4.

Lamb, R. (2013). How can Managers Use Participative Leadership Effectively? Retrieved January 1, 2018, from http://www.achievement.fm/participative-leadership. 
Leakey, L. (2012). Team cohesion. A review and directions for future research, Journal of Personal Psychology, 41(1), 63-105 https://doi.org/10.7176/JPP.

Ludviga, I., \& Kalvina, A. (2016). Exploring the Relationships between Job Satisfaction, Work Engagement and Loyalty of Academic Staff. International Journal of Economics and Management Engineering, $10 \quad$ (1), 99-101. https://doi.org/10.1016/j.sbspro.2013.10.540.

Lussier, N. R., \& Achua, C. F. (2010). Effective Leadership. London: Thomson SouthWestern.

Macey, R., Shneider, R.E. (2014). Leadership style, motivation and performance in International marketing channels: an empirical investigation of the USA, Finland and Poland. European Journal of Marketing, 37(1/2), 50-85. https://doi.org/10.1108/03090560310453939.

Malik, S. H. (2013). Leadership Behavior and Employee Job Satisfaction: A Study of PathGoal Theory in Telecom Sector. (Unpublished doctoral dissertation) Islamabad: National University of Modern Languages.

Malik, S. H., Aziz, S., \& Hassan, H. (2014). Leadership Behavior and Acceptance of Leaders by Subordinates: Application of Path Goal Theory in Telecom Sector. International Journal of Trade. Economics and Finance, 5(2), 10-14. https://doi.org/10.7763/IJTEF.2014.V5.364.

Monyazi, N. (2015). Job Satisfaction of Primary School Teachers in Botswana. The University of Botswana, Gaborone.

Northouse, P. (2013). Leadership Theory and Practice. Thousand Oaks: Sage Publications, Inc.

Northouse, P. G. (2010). Leadership Theory and Practice. (4 ${ }^{\text {th }}$ Ed.). Thousand Oaks, CA: Sage Publications.

Onimole, S. O. (2015), Work Design and Job Satisfaction, International Journal of Humanities and Social Science, 5 (1), 3-30. https://doi.org/10.1.1.902.6951\&rep.

Qureshi, M., \& Sajjad, S. (2015). An Empirical Analysis of the Impact of Compensation on Job Performance. European Scientific Journal, 11(4), 57-58. https://doi.org/ 10.18178/esj.6.1.50-53

Rahman, A., Mushaireen, M., Harnizam, Z \& Khazaniah., K., (2015). The study of employee satisfaction and its effects towards loyalty in hotel industry in Klang Valley, Malaysia. International Journal of Business and Social Science, 2(3), 9. https://doi.org/10.5539/ijbm.v4n10p152.

Riffat-un-Nisa, A. \& Bigger, S. (2013). Monitoring the quality of secondary education in the context of decentralization in Pakistan. The Journal of Psychology, 144 (3), 313326. https://doi.org/10.7763/IJTEF.2015.V6.471

Robbins, S. P. (2005). Organizational Behavior (1 $1^{\text {th }}$ Ed.) Pearson Prentice-Hall, Englewood Cliffs, N.J.

Salanova. A. \& Sanni K. (2016). Employee Satisfaction and Work Motivation. Research in Prisma Mikkeli, Mikkeli University of Applied Sciences.

Shafritz, J. M. (2010). Introducing Public Administration. Philadelphia: Longman Inc.

Sinek, S. (2014). Why good leaders make you feel safe. London: Prentice Hall.

Smit. (2016) Work stressors, job insecurity, union support, job satisfaction and safety outcomes within the iron ore mining environment, SA Journal of Human Resource Management, 14 (1), 719. https://doi: org/10.4102/sajhrm.

Temple, J. C. (2013). A Quantitative Study of Factors Contributing to Perceived Job Satisfaction of Information Technology Professionals Working in California Community Colleges. Doctoral Dissertation. University of La Verne.

Tomaževič, N., Seljak, J. \& Aristovnik, A. (2014). Factors influencing employee satisfaction in the police service: the case of Slovenia. Journal of Social Sciences 6(1), 64 - 73. https://doi.org/10.1108/PR-10-2012-0176.

Vigoda-Gadot, E., \& Talmud, I. (2013). Organizational Politics and Job Outcomes: The Moderating Effect of Trust and Social Support. Journal of Applied Social Psychology, 2 (8), 26-28. https://doi.org/10.1111/j.1559-1816.2010.00683.x. 
Yang, X., W. Wang, (2013). Exploring the Determinants of Job Satisfaction of Civil Servants in Beijing, China. Public Personal Management. Journal of Management, 2 (1), 2-3. https://doi.org/1G1-352752362.

Yoder, G. M., \& Staudohor, W. F. (2014). Directive leadership style, participation of employees, performance and job satisfaction at work. Journal of Applied Psychology, 70, 342 - 353. https://doi.org/10.18775/jibrm.1849-8558.2015.33.3004.

Yun, S., Cox, J., \& Sims, H., (2017), Leadership and Teamwork: The Effects of Leadership and Job Satisfaction on Team Citizenship, International Journal of Leadership Studies, 2(3), 171-193. https://doi.org/10.4018/978-1-5225-5490-5.ch017.

Zhu, H., Xie, V., \& Warner, A., \& Guo, M., (2015). Transactional and transformational leadership impacts on organizational learning, Journal for East European Management Studies, 14 (2), 145-165. https://doi.org/10.5771/0949-6181-2009-2144. 